\title{
The Relationship between Learner Autonomy and Willingness to Communicate (WTC) in Iranian EFL Learners
}

\author{
Shahab Khaki \\ College of Foreign Languages and Literature, Science and Research Branch, IAU, Tehran, Iran \\ E-mail: shahab.khaki@yahoo.com
}

Received: 14-05-2013

Accepted: 21-06-2013

Published: 01-09-2013

doi:10.7575/aiac.ijalel.v.2n.5p.97

URL: http://dx.doi.org/10.7575/aiac.ijalel.v.2n.5p.97

\begin{abstract}
WTC is very important for English learners. Without WTC it is impossible to use the target language. On the other hand, developing learner autonomy as the independence in one's own learning is considered a crucial goal of education. More important than that learner autonomy in WTC is a necessity that has to be considered in language education. In this study, the researcher investigated whether there is any statistically significant relationship between learner autonomy and WTC in Iranian EFL learners. To this end, 77 English learners were homogenized out of 100 advanced learners. A learner autonomy questionnaire and a WTC scale, for measuring trait-like WTC, was given to them; and they were observed, for measuring situational WTC, for 6 sessions. The quantitative data gathered through these instruments were analyzed to determine the degree of correlation between these two constructs. The results demonstrated a significant and strong relationship between learner autonomy and trait-like WTC in Iranian EFL learners and a significant but weak correlation between learner autonomy and situational WTC in Iranian EFL learners. So it can be concluded that a significant relationship between learner autonomy and WTC can be seen in Iranian EFL learners. The regression analysis provided further support for this result.
\end{abstract}

Key Words: Learner autonomy, Willingness to communicate, WTC, EFL learners.

\section{Introduction}

After a convincing discussion upon the shortcomings of the methods, such as the passive role of students and the authoritative role of teachers, Kumaravadivelu (2006) maintains that the concept of method is dead and teaching methodology has entered into the postmethod era. One of the building blocks of postmethod perspectives is the concept of autonomy, and the emphasis should be put on developing both learner and teacher autonomy.

Learner autonomy has a long history, and recently it has become globalized; moreover, from the 1971 onwards that is the birth of learner autonomy, in 1997, a breakthrough in this field can be seen in that almost all the titles of the books at that time contained the word autonomy and the title of "autonomy movement" that has been chosen for it, claims its importance (Smith, 2008), and it can lead to a paradigm shift in language learning (Jacobs \& Farrell, 2001). In the literature, the importance of learner autonomy has almost always been emphasized, and it can be readily inferred that success in learning for learners depends on their being autonomous (Little, 1995; Scharle \& Szabo, 2000), and the governing goals of teaching are to produce learners that can act and think more autonomously and a strategy for developing learner autonomy (Littlewood, 1996). Learner autonomy is a crucial need for learners (Littlewood, 1999), and according to Little (2007), it should be at the center of language teaching and learning. The importance of the learner autonomy is sometimes explained in terms of a positive relationship between present and future learning, and if autonomy is developed and enhanced in learners, they will achieve their learning goals and if they achieve their learning goals, they will have a positive attitude toward their future learning (Little, 1995; Scharle \& Szabo, 2000). Therefore, developing and enhancing learner autonomy would be considered as a guarantee for the learners' present and future success.

Autonomy can be seen as an attitude or a capacity towards learning in which one can take the responsibility for his own learning (Dickinson, 1995; Little, 1995; White, 1995). Also, autonomy is a process and not a product, and a person can only work toward autonomy (Thanasoulas, 2000).

One of the important concepts that might seem related to learner autonomy is WTC which was first presented for L1 by McCroskey and Baer in 1985 (MacIntyre, 2007), but recently it is emerging as a concept to account for individuals' L1 and L2 communication (Yashima, 2002).

From the birth of WTC, it has been gaining so much importance in the literature that recently it has been considered as one of the most important concepts which can account for the learners' progress in the field of education. If learners have a high WTC they will be effective in their learning and others will have a positive attitude toward them (McCroskey \& Richmond, 1987); moreover, it is an all-important construct which significantly contributes to all aspects of one's achievements (Richmond \& Roach, 1992). By creating WTC in language learners, language learning may achieve its social and political goal; moreover, the ultimate goal of second/foreign language education should be creating and fostering WTC in students (MacIntyre, Clement, Dornyei, \& Noels, 1998).

Kang (2005) supposes that if WTC is created in learners there is the probability that they become more autonomous. It was found, according to Haghi (2009) in Iranian EFL learners, that there is a significant relationship between perceived 
self-efficacy and learner autonomy in high proficient Iranian EFL learners. Brown (2007), on the other hand, believes that self-efficacy and WTC are related. Moreover, a set of common factors influencing both learner autonomy and WTC can be seen in the literature upon them, namely, attitudes and beliefs, culture, gender, motivation, self-confidence, and self-esteem. Regarding their common importance Zarrinabadi and Abdi (2011) consider learner autonomy and WTC as parallel and claim that having a high WTC and being autonomous are prerequisites for being successful in the new era of methodology.

\subsection{Purpose of the Study}

Different learners attend educations, but they are not familiar with the concepts of autonomy and WTC and their importance. It is human's nature to be autonomous. However, having the ability and blessing to be autonomous does not mean that we are completely autonomous; rather, during life and through interventions autonomy should be acquired (Little, 2007). A problem that has to be solved in educational environments is that the significance that learner autonomy has to have is not observed, and the concept of learner autonomy is tarnished (Benson \& Voller, 1997, as cited in Thanasoulas, 2000), so care should be taken to prevent marginalization of learner autonomy, and put it at the center of language teaching and learning (Little, 2007). This is also true about WTC, so both concepts are not that much observed in the educational institutions, as they should be.

$\mathrm{Yu}, \mathrm{Li}$, and Gou (2011) believe that for many language learners, the main purpose in learning a second language is the use of it, i.e. and language is acquired to be used, and WTC is the main cause of second language (L2) use. Therefore, it can be inferred that learner autonomy is crucial in learners' success in learning a second or foreign language, this success, however, is not complete without the use of the language they are learning, because " $\ldots$ autonomy in language learning and autonomy in language use are two sides of the same coin" (Little, 2007, p. 13). Consequently, it can be claimed that autonomy in WTC is a necessity that must be observed in educational environments, so the purpose of the present study was to demonstrate whether there is a statistically significant relationship between learner autonomy and WTC in Iranian EFL learners. Thus, this study was based on the following research question and null hypothesis:

RQ: Is there any statistically significant relationship between learner autonomy and WTC of Iranian EFL learners?

H0: There is no statistically significant relationship between learner autonomy and WTC of Iranian EFL learners.

\section{Review of the Related Literature}

\subsection{Learner Autonomy}

Personal autonomy which is the origin of autonomy in learning is currently understood in the field of moral and political philosophy and has a long history in the field of western political philosophy (Benson, 2008). In about twenty years after the Second World War, autonomy, self-access, and self-direction which all refer to the same concept entered into the field of education due to some reasons like, the role change of the learner from a passive participant to a consumer and the reaction against behaviorism, and it became more and more known as the time passed (Gremmo \& Riley, 1995).

Yevs Chalon is considered to be the father of autonomy (Egel, 2009), but Holec's bringing of the term autonomy in the field of language learning is considered as the point of the beginning of the debate about this concept (Schmenk, 2005). Holec presented a well-known definition for this concept in 1981 (as cited in Ustunluoglu, 2009, p. 149; Cotterall, 2000, p. 109; Vorla, \& Yilmaz, 2010, p. 238): "learner autonomy is the ability to take charge of one's own directed learning". Littlewood (1999), however, states that despite varying definitions for autonomy they all have two points in common, namely, students should take responsibility for their own learning and they should possess processes that traditionally belonged to the teachers, like evaluation. Also, expressions like 'independent learning' and 'self-directed learning' (Benson, 2001), and self-regulation or auto-control (Wenden, 1995) are very often used as synonyms for autonomy.

An autonomous learner accepts that his own effort is crucial in his learning; likes to cooperate with others;

regularly monitors himself; and uses available opportunities for his benefit (Scharle \& Szabo, 2000). Successful teachers are the teachers who have always been autonomous (Little, 1995). As Barfield et al. (2001) claim, teacher autonomy can be interpreted in two different but interrelated ways: an autonomous teacher develops and enhances autonomy in the learners, and she tries to have control over what she does. So a teacher should experience autonomy herself and develops this skill to be prepared to move the students toward autonomy (Ustunluoglu, 2009), because developing teacher autonomy overlaps with the principles of fostering learner autonomy (Barfield et al., 2001). As far as autonomy needs educational intervention to be achieved, so teacher plays a crucial role in achieving this goal (Thanasoulas, 2000). Egel (2009) concludes that learner autonomy, the classroom, and the teacher are interdependent and go hand in hand.

Some factors influence autonomy, so recognizing them would be helpful in developing autonomy. These factors are:

- Belief as the probability dimension of a concept and attitude as the evaluative dimension (Fishbein \& Raven, 1962) can influence autonomy to a great degree (Hurd, 2005; Cotterall, 1995; Victori \& Lockhart, 1995; Yang, 1999; Thanasoulas, 2000).

- Culture as a set of rules that have to be known to be able to live in a society (Wardhaugh, 2006) also influences autonomy because certain cultural traits might either facilitate or inhibit learner autonomy (Crookall \& Ho, 1995; Schmenk, 2005; Benson, 2006; Egel, 2009). Also politics should support autonomy to be enhanced (Carson, 2008).

- Gender influences autonomy in that females tend to be more autonomous than male learners (Bekker \& Assen, 2008; Ustunluoglu, 2009; Varol, \& Yilmaz, 2010).

- $\quad$ Learning Strategies as complex procedures that individuals apply to tasks (O'Malley \& Chamot, 1990) prepare learners to be autonomous (Hsiao \& Oxford, 2002). 
- Motivation which controls the direction and magnitude of human behavior (Dornyei, 2001) has an important impact on autonomy (Dickinson, 1995; Benson, 2006; Ustunluoglu, 2009); in that there is a bidirectional relationship between autonomy and motivation (Spratt, Humphreys, \& Chan, 2002), and they both have political dimensions as well (Ushioda, 2006). However, only intrinsic motivation is necessary for autonomy enhancement (Noels, Pelletier, \& Vallerand, 2000; Scharle \& Szabo, 2000).

- $\quad$ Self-confidence plays an important role in development of responsibility and autonomy in that there is a mutual relationship between them (Scharle \&Szabo, 2000).

- Self-esteem influences learner autonomy by influencing learners' attitude toward the target language (Thanasoulas, 2000).

Scharle and Szabo (2000) believe that developing and fostering responsibility and autonomy in learners is gradual and can be classified into three stages. The first stage is raising awareness; the second stage is changing attitudes; and the third stage is transferring roles.

\subsection{Willingness to Communicate (WTC)}

Three main researches led to the emergence of WTC (Matsuoka \& Evans, 2005). They are unwillingness to communicate (Burgoon, 1976); predisposition toward verbal behavior (Mortenson, Arntson, \& Lustig, 1977; as cited in McCroskey \& Baer, 1985); and shyness (McCroskey \& Richmond, 1982). All of these researches had prominent shortcomings and could not operationalize what they had claimed (McCroskey \& Baer, 1985). Finally, McCroskey and Baer (1985) presumed that there is a trait-like and personality-based predisposition that is relatively consistent across a variety of communication contexts and types of receivers, this concept underlies WTC and is the reason why people communicate more or less across communication situations. They devised WTC scale and could demonstrate its validity; therefore, they could operationalize what they had claimed.

WTC can be defined as “... an individual's volitional inclination towards actively engaging in the act of communication in a specific situation, which can vary according to interlocutor(s), topic, and conversational context, among other potential situational variables" (Kang, 2005, p. 291). In the literature, two orientations toward the study in the field of WTC can be seen. The first studies pay more attention to a trait-like predisposition for WTC; however, later studies pay more attention to the situational construct for WTC (Kang, 2005); nevertheless, WTC is considered as being a dual characteristic construct (Cao \& Philp, 2006), namely trait-like WTC and situational WTC, and they should be considered as complementary and investigate both in researches upon WTC (MacIntyre, Babin, \& Clement, 1999).

Variables that influence trait-like WTC are called "antecedents" of WTC that are in mutual causality with each other (McCroskey \& Richmond, 1987) and they are:

- Age: the relationship between age and WTC is gender-based, in that, as females grow up their WTC decreases, but as males grow up heir WTC increases (Donovan \& MacIntyre, 2004).

- Anomie and alienation which lead to less WTC (McCroskey \& Richmond, 1987; MacIntyre et al., 1999).

- Anxiety (MacIntyre, et al., 1998; Yashima, 2002; MacIntyre, 2007).

- Attitude is highly correlated with WTC (Yashima, 2002; Yashima et al., 2004; Yu, 2009); however, Peng (2007) believes that attitude toward the learning situation does not play any predicting role in determining WTC.

- Communication apprehension which is one's fear in communication with another person (McCroskey, 1977) is an all-important factor in WTC (McCroskey \& Richmond, 1987; Barraclough, et al. 1988; Richmond et al., 1989; Kang, 2005; Yu, 2009; Yu et al., 2011).

- Communication skills/competence and self-perceived communication competence (McCroskey \& Richmond, 1987; Barraclough, et al. 1988; Richmond, McCroskey, \& McCroskey, 1989; MacInyre, et al., 1998; MacIntyre et al., 1999; Hashimoto, 2002; Yashima, 2002; Yashima, Zenuk-Nishide, Shimizu, 2004; kang, 2005; Yu, 2009; Yu et al., 2011).

- Culture is an important antecedent in which conditions for fostering WTC should be present (McCroskey \& Richmond, 1987; Barraclough, Christophel, \& McCroskey, 1988; Sallinen-Kuparinen, McCroskey, \& Richmond, 1991; Matsuoka \& Evans, 2005; Cao \& Philp, 2006; MacIntyre, 2007).

- Emotional stability/neuroticism (MacIntyre et al., 1999).

- Gender: the underlying factors for WTC differs in males than females (Donovan \& MacIntyre, 2004), and girls are more willing to communicate than boys (MacIntyre, Baker, Clement, \& Donovan, 2002); however Milani (2008) found no difference between males and females regarding WTC.

- Introversion/extroversion in which extroverts show more WTC (McCroskey \& Richmond, 1987; MacIntyre et al., 1999).

- Motivation (Hashimoto, 2002; Yashima, 2002; Yashima et al., 2004; Peng, 2007; MacIntyre, 2007).

- Self-confidence whose high degree leads to a high WTC (MacIntyre, et al., 1998; Cao \&Philp, 2006).

- Self-esteem whose high degree leads to a high WTC (McCroskey \& Richmond, 1987; MacIntyre et al., 1999). Situational WTC is explained through some models, e.g. MacIntyre et al.'s model (1998) in which both trait-like and situational factors influencing WTC are explained. This model integrates psychological, linguistic and communicative variables to describe, explain, and predict second language communication. It is hypothesized that all social, affective, cognitive and situational variables influence one's WTC in an L2, which in turn predicts one's actual use of that language. The model that they have presented is formed in a pyramid-shaped structure with six categories or variables called layers. 


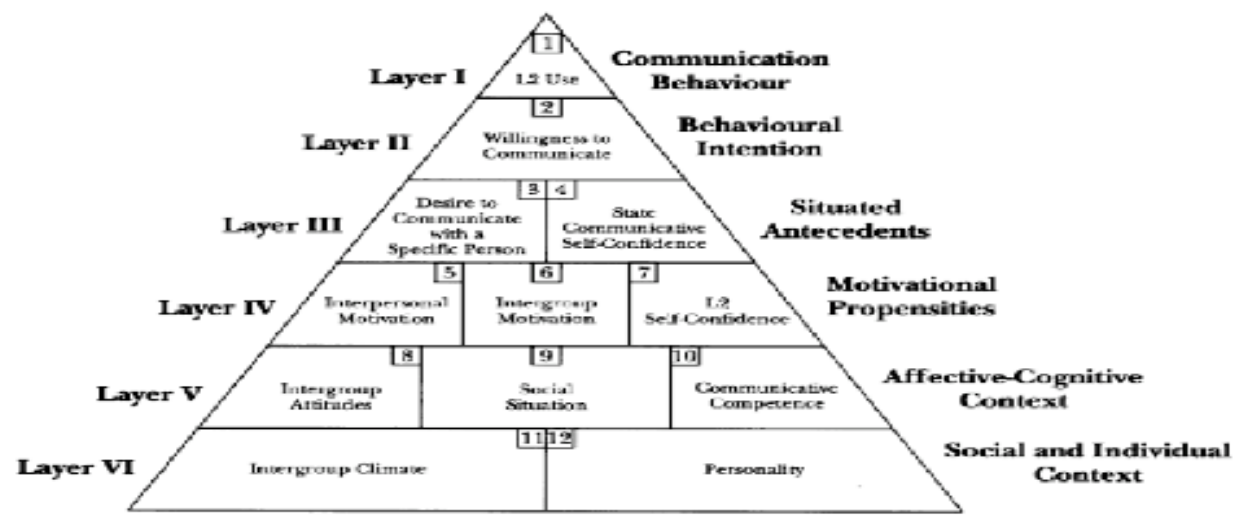

Figure 2.1. Heuristic model of variables influencing WTC (Source: MacIntyre, Clément, Dörnyei \& Noels, 1998, p. 547)

The pyramid is chosen as heuristic because it allows us to begin our discussion at the moment of communication. Reaching the point at which one is about to communicate in the L2 is influenced by both immediate situational factors as well as more enduring influences. The pyramid shape shows the immediacy of some factors and the relatively distal influence of others, so the lower levels make a basis for the other upper levels. In this model the first three layers are situational influences which are seen as transient and dependent on the specific context in which a person functions at a given time; and the last three layers are enduring influences, which refer to stable, long-term properties of the environment or person that would apply to almost any situation.

Yashima (2002) and Yashima et al. (2004) not only support the L2 communication model, but also they support the applicability of MacIntyre et al.'s (1998) conceptual model in an EFL context. In a study by MacIntyre, Baker, Clement, and Conrod (2001), they found out that social support from friends is related with higher levels of WTC outside classroom, but not inside the classroom, because this way, students have less feeling of anxiety and high selfconfidence, so this is an evidence that WTC in the authentic context is influenced by interlocutors. Clement, Baker, and MacIntyre (2003) say that WTC model does not explicitly deal with situations in which status-based linguistic accommodation and other social pressures might create L2 use against the personal preference of the speaker. Also Compton (2007) claims that this model may not be comprehensive enough to explain WTC in all L2 environments.

For fostering WTC a set of strategies can be found that may come in handy:

- Enhancing students' interest in different cultures and international affairs and activities, as well as reducing anxiety, and building confidence in communication (Yashima, 2002).

- Giving interesting topics that learners have background knowledge and experience for them; and discussing about several topics in a lesson (Kang, 2005).

- Reducing anxiety and enhancing motivation in learners (Hashimoto, 2002).

- Brainstorming, taking a survey, and letting L2 learners bring choose their own topics, because this raises students' interest (Kang, 2005).

- Decreasing the number of learners in a group that leads to more responsibility and security (Kang, 2005).

- Providing opportunities for students along with triggering their intention to participate in classroom interaction, by the use of teacher interaction strategy which refers to an interaction device a teacher uses to interact with his/her students in the classroom (Lee \& Ng, 2010).

- Letting the learners know that their errors and mistakes are not considered as negative and weak point for them (Riasati \& Noordin, 2011).

- Using technology and avoiding adherence to the traditional ways of teaching for example the use of on-line chat for problem-solving, because it provides a more comfortable environment and enhances students' WTC (Freiermuth \& Jarrell, 2006). And the use of digital on-line group games because they are able to increase students' enthusiasm, lower anxiety, and improve WTC (Reinders \& Wattana, 2011).

\section{Method}

\subsection{Participants}

The participants of this study were100 male and female advanced learners in Tehran, Iran. For the purpose of research, those whose scores were within the range of one standard deviation above the mean and one standard deviation below the mean were selected. By doing so, 77 of these 100 participants consisting of 41 male learners and 36 female learners were selected for this study. The participants' mean age was 22 in this study.

\subsection{Instruments}

In order to accomplish the purpose of the present study four measuring instruments were utilized, namely, a language proficiency test; a learner autonomy questionnaire; a WTC scale, for trait-like WTC; and a WTC classroom observation scheme, for situational WTC all of which provided quantitative data for this research. Finally, SPSS version 16.0 software was used for analyzing the data.

3.2.1 Language Proficiency Test

In order to homogenize the participants, a language proficiency test -- a TOEFL test -- was used. Before administering the test to the main group, the test had been piloted in order to have essential modifications. The reliability of the TOEFL test that was used in this study had been investigated by using Cronbach's alpha reliability estimation. Table 3.1 demonstrates the reliability of the TOEFL test. 
Table 3.1 Reliability Statistics of the TOEFL Test

\begin{tabular}{rrr}
\hline Cronbach's Alpha & N of Items \\
\hline .756 & \\
\hline
\end{tabular}

\subsubsection{Learner Autonomy Questionnaire}

Learner autonomy was measured through scores obtained from the learner autonomy questionnaire, a 5-point Likertscale questionnaire, which had been designed by Zhang and Li (2004, as cited in Dafei, 2007). This questionnaire includes 21 items in two parts. The first part has eleven items, and the second part includes ten items all of which have five answers from A to E. Options were valued from 1 to 5, i.e. option A equaled 1 and option E equaled 5. Dafei (2007) claims this questionnaire has been proved to have high content validity and high reliability.

3.2.3 WTC Scale

The WTC scale devised by McCroskey and Baer (1985) was utilized to gather data about learners' trait-like WTC. This scale is a valid operationalization of the WTC construct. Later in 1989, Zakahi and McCroskey found a strong support for the WTC measure. This scale is a 20 -item probability-estimate scale. Eight of the items in the scale are fillers, and the remaining twelve items are scored to yield a total score. These twelve items generate a total score, four context-type scores, and three receiver-type scores. The sub-scores generate lower reliability estimates, but generally high enough to be used in research studies. Participants indicate the percentage of times they would choose to communicate in each type of situation, from 0 (never) to 100 (always) (McCroskey, 1992).

As McCroskey (1992) claims, the face validity of the instrument is strong, and the results of the extensive research indicate the predictive validity of the instrument. Alpha reliability estimates for this instrument have ranged from 0.85 to well above 0.90 . The instrument has been used in a variety of studies, for example, studies on students who are willing to communicate in the classroom (Chan, 1988, as cited in McCroskey, 1992) and as basis for kid's WTC scale in first language acquisition (FLA) (Birjandi \& Amiri, 2011).

3.2.4 WTC Classroom Observation Scheme

The classroom observation scheme, which was used in this study, is devised by Cao and Philp (2006). This tally chart has two parts. The first part has seven items which measures students' situational WTC in the presence of the teacher, and the second part has five items which measures students' situational WTC in the absence of the teacher. Seedhouse (2004) believes that a number of five to ten sessions are enough and valid for classroom research. In this study, the researcher chose to observe the participants for six one-hourly sessions. The mean was calculated and a number was reported for each participant which indicates their situational WTC estimate.

\subsection{Procedure}

First, the proficiency test had been piloted in order to estimate its reliability and have essential modifications. Second, the test was administered, and the participants were homogenized. Third, the Learner Autonomy Questionnaire and the WTC Scale were given to participants. The researcher allocated certain amount of time and tried to set the same place in order to have almost the same setting for all of the participants. Fourth, the researcher observed the participants in their classrooms for six one-hourly sessions.

\subsection{The Design of the Study}

The present study is descriptive since it aims to determine the frequency and range of learner autonomy and WTC of the Iranian EFL learners, and it is also correlational since it aims to find a relationship between the variables under study. This study is also an ex post facto type, in which there is no treatment (Mackey \& Gass, 2005). In this study, one of the non-probability or purposive sampling ways called convenience, accidental or opportunity sampling was utilized, in which the researcher selects whoever is available and is willing to participate in the study. And regarding the way questionnaires were distributed the self-administered method of questionnaire distribution was utilized, in which the questionnaires were directly presented to the respondents in the presence of the researcher (Cohen, Manion, \& Morrison, 2007).

The observation was a structured observation, in which the researcher knew what he was going to observe, and it was also a naturalistic and complete participant observation, in which the researcher played the role of an insider and did not mention that he was a researcher while observing (Cohen, Manion, \& Morrison, 2007). The tally chart, used for the observation, was a low inference one in which it was clearly enough in terms of the behavioral characteristics; could be coded easily at the time of observation; and did not need any judgment (Chaudron, 1988, as cited in Mackey \& Gass, 2005).

\section{Results and Discussion}

The objective of the present study was to demonstrate whether there is a statistically significant relationship between learner autonomy and WTC in Iranian EFL learners, and in order to achieve this objective, the collected data were analyzed through descriptive and inferential statistics.

4.1 Descriptive Statistics of the TOEFL Test

In order to homogenize the hundred participants of this study, a TOEFL test was administered. The descriptive statistics results of the TOEFL test is presented in table 4.1. This table demonstrates that the mean of the scores was 77.56, and the standard deviation was 3.72. So to homogenize the participants, 77 students whose scores fall within the range of one standard deviation above the mean and one standard deviation below the mean were selected. 
Table 4.1. Descriptive Statistics of the TOEFL Test

\begin{tabular}{lcrrrrr}
\hline & N & Minimum & Maximum & Mean & \multicolumn{2}{c}{ Std. Deviation Variance } \\
\hline TOEFL.Scores & 100 & 69.00 & 86.00 & 77.56 & 3.72 & 13.84 \\
Valid N & & & & & & \\
(listwise) & 100 & & & & & \\
\hline
\end{tabular}

\subsection{Descriptive Statistics of Learner Autonomy Questionnaire}

Table 4.2 demonstrates the descriptive statistics of the learner autonomy questionnaire. According to this table the minimum of the scores was 61 ; the maximum of the scores was 88 ; the mean was 75.18 ; the standard deviation was 6.31 ; and the variance was 39.83 .

Table 4.2. Descriptive Statistics of Learner Autonomy Questionnaire

\begin{tabular}{lccccrrr}
\hline & & \multicolumn{2}{c}{ Minimu } & Maximu & & $\begin{array}{c}\text { Std. } \\
\text { Deviation }\end{array}$ & Variance \\
\hline $\begin{array}{l}\text { Autonomy.Questionn } \\
\text { aire }\end{array}$ & 77 & 61.00 & 88.00 & 75.18 & 6.31 & 39.83 \\
Valid N (listwise) & 77 & & & & & \\
\hline
\end{tabular}

\subsection{Descriptive Statistics of the WTC Scale}

The descriptive statistics of the WTC scaleis summarized in Table 4.3 in which the minimum of the scores was 60; the maximum of the scores was 93.33; the mean was 73.39; the standard deviation was 7.07; and the variance was 49.98 .

Table 4.3. Descriptive Statistics of the WTC Scale

\begin{tabular}{|c|c|c|c|c|c|c|}
\hline & $\mathrm{N}$ & Minimum & Maximum & Mean & Std. Deviation & $\begin{array}{c}\text { Varian } \\
\text { ce }\end{array}$ \\
\hline WTC.Scale & 77 & 60.00 & 93.33 & 73.39 & 7.07 & 49.98 \\
\hline $\begin{array}{l}\text { Valid N } \\
\text { (listwise) }\end{array}$ & 77 & & & & & \\
\hline
\end{tabular}

\subsection{Descriptive Statistics of the WTC Classroom Observation Scheme}

The last instrument that was used in this study was WTC classroom observation scheme. As table 4.4 shows the minimum of the scores was 10.65 ; the maximum of the scores was 77.65 ; the mean was 28.94 ; the standard deviation was 12.36; and the variance was 152.69 .

Table 4.4. Descriptive Statistics of the WTC Classroom Observation Scheme

\begin{tabular}{|c|c|c|c|c|c|c|}
\hline & $\mathrm{N}$ & Minimum & Maximum & Mean & Std. Deviation & $\begin{array}{c}\text { Varianc } \\
\mathrm{e}\end{array}$ \\
\hline $\begin{array}{l}\text { WTC.Tally.Cha } \\
\mathrm{rt}\end{array}$ & 77 & 10.65 & 77.65 & 28.94 & 12.36 & 152.69 \\
\hline $\begin{array}{l}\text { Valid N } \\
\text { (listwise) }\end{array}$ & 77 & & & & & \\
\hline
\end{tabular}

\subsection{Testing the Null Hypothesis}

As it was mentioned, WTC is considered as possessing two parts, namely trait-like and situational, and it is emphasized in the literature that both parts be measured when a researcher tends to do so (MacIntyre et al., 1999; Kang, 2005; Cao \& Philp, 2006); therefore, in this study, the researcher first calculated Pearson product correlation for data gathered from learner autonomy questionnaire and WTC scale, and then calculated Pearson product correlation for data gathered from learner autonomy questionnaire and WTC classroom observation scheme. The researcher also used linear regression for determining the degree of the predictability of learner autonomy construct for both trait-like and situational WTC.

Table 4.5 shows the degree of correlation between learner autonomy and trait-like WTC. As the table depicts, a significant and strong relationship can be observed between learner autonomy and trait-like WCT $(\mathrm{r}=.55, \mathrm{P}=.000<$ .05 ; it represents a strong effect size). 
Table 4.5. Correlation between learner autonomy and trait-like WTC

\begin{tabular}{llrr}
\hline & & $\begin{array}{c}\text { Autonomy.Que } \\
\text { stionnaire }\end{array}$ & WTC.Scale \\
\hline Autonomy.Questionnaire & Pearson Correlation & 1 & $.556^{* *}$ \\
& Sig. (2-tailed) & & .000 \\
& $\mathrm{~N}$ & 77 & 77 \\
\hline WTC.Scale & Pearson Correlation & $.556^{* *}$ & 1 \\
& Sig. (2-tailed) & .000 & \\
& $\mathrm{~N}$ & 77 & 77 \\
**. Correlation is significant at the 0.01 level (2-tailed). & &
\end{tabular}

Table 4.6 demonstrates the degree of correlation between learner autonomy and situational WTC. Based on the data represented in this table it can be seen that learner autonomy shows a significant but weak correlation with situational WTC $(r=.25, \mathrm{P}=.025<.05$; it represents a weak effect size $)$.

Based on the data represented in Table 4.5 and Table 4.6, the correlation between learner autonomy and trait-like WTC is significant and strong, also the correlation between learner autonomy and situational WTC is significant and weak but enough to judge that there is a significant relationship; consequently, it can be judged that the null hypothesis is rejected.

Table 4.6. Correlation between learner autonomy and situational WTC

\begin{tabular}{llrr}
\hline & & $\begin{array}{c}\text { Autonomy.Ques } \\
\text { tionnaire }\end{array}$ & $\begin{array}{r}\text { WTC.Tal } \\
\text { ly.Chart }\end{array}$ \\
\hline Autonomy.Questionnaire & Pearson Correlation & 1 & $.256^{*}$ \\
& Sig. (2-tailed) & .025 \\
& $\mathrm{~N}$ & 77 & 77 \\
\hline WTC.Tally.Chart & Pearson Correlation & $.256^{*}$ & 1 \\
& Sig. (2-tailed) & .025 & \\
& $\mathrm{~N}$ & 77 & 77 \\
\hline * Correlation is significant at the 0.05 level (2-tailed) & &
\end{tabular}

In the abundance of literature upon learner autonomy and WTC, a number of researches which the findings of this study are in line with can be found. The emphasis on the central, crucial, and governing role of the learner autonomy (Little, 1995 \& 2007; Litlewood, 1996 \&1999; Scharle \& Szabo, 2000), and WTC (Kang, 2005; Riasati \& Noordin, 2011; Yu et al., 2011; Zarrinabadi \& Abdi, 2011) in education is obvious in the related literature upon both, especially when Zarrinabadi and Abdi (2011) clearly consider both learner autonomy and WTC as prerequisites for being successful in the new methodology era. By developing and enhancing learner autonomy (Little, 1995) and WTC (MacIntyre et al., 1998 ) in learners, they would be able to achieve their goals which lead to their present and future success. Based on this evidence, it seems logical to suggest that the learner autonomy and WTC are related.

Kang (2005) supposes that if WTC is created in learners there is the probability that they become more active inside and outside classroom and, hence, become more autonomous, so based on this assumption, there can be a relationship between learner autonomy and WTC. Haghi (2009) demonstrated a significant relationship between perceived selfefficacy and learner autonomy in high proficient Iranian EFL learners, and a relationship between these two variables in low proficient Iranian learners; on the other hand, Brown (2007) believes that self-efficacy and WTC are related. Therefore, it can be again suggested that there is a relationship between learner autonomy and WTC.

One of the reasons that led to the emergence of autonomy was the change in the role of the learners from passive participants to active ones that play an important part in the classroom (Gremmo \& Riley, 1995); moreover, having an active role requires interaction and communication which is impossible without talk caused by WTC, so autonomy grow out of interaction.

One of the domains of autonomy is autonomy as a communicator which refers to the fact that a person becomes autonomous in communicating in specific situations (Littlewood, 1996). This implies that the possibility of being a relationship between learner autonomy and situational WTC which is a part of WTC seems plausible.

A very important concept in autonomy studies is that of relatedness in which developing and enhancing autonomy is possible only in an interpersonal environment and as a product of interdependence (Ryan, as cited in Littlewood, 1996; Little, 2007); moreover, Carson (2008) also says that autonomy development is possible only through interaction. McCroskey and Baer (1985) claimed that the more willing a person is to communicate, the more likely that person is to develop interpersonal relationship. Donovan and MacIntyre (2004), also, believe that being willing to communicate leads to relationship building and interpersonal influence. This fact shows that learner autonomy and WTC are related, because without WTC relatedness which is considered crucial in developing autonomy is not possible. 
Culture of a society may facilitate or inhibit the development of learner autonomy (Crookall \& Ho, 1995) and WTC (Sallinen Kuparinen et al., 1991; Matsuka \& Evans, 2005), and as far as a culture in which interaction and interdependence are norms can develop both learner autonomy and WTC, it can again be concluded that they are both related.

When the aim of an educational system is to enhance learner autonomy (Scharle \& Szabo, 2000) and/or WTC (Lee \& $\mathrm{Ng}, 2010$ ) interaction, cooperation, and opportunity provision is considered as important strategies. This shows that by having these strategies both learner autonomy and WTC would be enhanced, because they may be related.

In developing learner autonomy a classroom in which collaboration and interaction is emphasized is a key factor (Egel, 2009), and class participation is mainly based on the learners' general tendency towards communication, i.e. trait-like WTC (Chan \& McCroskey, 1987; Zarrinabadi \& Abdi, 2011). Again this is further evidence that Learner autonomy and WTC are related, and a further evidence for the higher degree of correlation between learner autonomy and trait-like WTC than the degree of correlation between learner autonomy and situational WTC.

In this study, the greater variance of the scores obtained from WTC classroom observation scheme (152.69) than the variance of the scores obtained from WTC scale (49.98) and the higher degree of correlation between learner autonomy and trait-like WTC than what was demonstrated between learner autonomy and situational WTC can be related to some common and important factors, explained above, underlying learner autonomy and trait-like WTC. It is stated in the literature that maybe a person has a high trait-like WTC, but when put in a situation to speak; other factors may intervene and facilitate or inhibit talk (MacIntyre et al., 1998; MacIntyre et al., 1999; MacIntyre, Baker, Clement, \& Conrod, 2001; Kang, 2005, Cao \& Philp, 2006). These factors such as group size, familiarity with the interlocutors, and topic of discussion (Kang, 2005) may influence situational WTC and finally WTC. This can be considered as a support for the lower degree of correlation between learner autonomy and situational WTC.

Scharle and Szabo (2000), however, believe that autonomous learners just try to learn the subject matter and are not after pleasing teachers or influencing others; moreover, they are not especially eager for teamwork, they just do that for their benefit and that of the others. This is contrary to the findings of this study, because based on their claim autonomous learners may not be willing to communicate.

The following tables show the data calculated through linear regression upon the degree of predictability that learner autonomy can provide for trait-like WTC.

Table 4.7. Variables Entered/Removed ${ }^{\mathrm{b}}$

\begin{tabular}{llll}
\hline Model & Variables Entered & $\begin{array}{l}\text { Variables } \\
\text { Removed }\end{array}$ & Method \\
\hline 1 & $\begin{array}{l}\text { Autonomy.Questio } \\
\text { nnaire }^{\text {a }}\end{array}$ & & . Enter \\
\end{tabular}

a. All requested variables entered.

b. Dependent Variable: WTC.Scale

As Table 4.8 demonstrates, $\mathrm{R}$ is 0.556 which is the correlation coefficient between the two variables, and $\mathrm{R}$ square is 0.309. Based on the data obtained from Table 4.8, it can be inferred that learner autonomy can predict 30 percent of trait-like WTC $(\mathrm{R}=.556, \mathrm{R}$ Square $=.30)$.

Table 4.8. Model Summary

\begin{tabular}{|c|c|c|c|c|}
\hline Model & $\mathrm{R}$ & R Square & Adjusted R Square & $\begin{array}{l}\text { Std. Error of the } \\
\text { Estimate }\end{array}$ \\
\hline 1 & $.556^{\mathrm{a}}$ & .309 & .300 & 5.91641 \\
\hline
\end{tabular}

Table 4.9 demonstrates the results of the ANOVA that turned out to be significant $\left(\mathrm{F}=33.52, \mathrm{P}=.000<.05 \omega^{2}=.29\right.$; it represents a large effect size).

Table 4.9. ANOVA $^{\mathrm{b}}$

\begin{tabular}{llrrrrr}
\hline Model & & Sum of Squares & df & Mean Square & F & Sig. \\
\hline 1 & Regression & 1173.509 & 1 & 1173.509 & 33.525 & $.000^{\mathrm{a}}$ \\
& Residual & 2625.297 & 75 & 35.004 & & \\
& Total & 3798.806 & 76 & & & \\
\hline
\end{tabular}

a. Predictors: (Constant), Autonomy.Questionnaire

b. Dependent Variable: WTC.Scale 
Table 4.10 indicates the coefficients according to which the standardized Beta coefficient is significant $(\mathrm{B}=.556, \mathrm{t}=$ $5.79, \mathrm{P}=.000<.05)$. The data represented in Table 4.9 and 4.10 indicate that learner autonomy significantly predicts trait-like WTC.

Table 4.10. Coefficients ${ }^{\mathrm{a}}$

\begin{tabular}{|c|c|c|c|c|c|}
\hline \multirow[b]{2}{*}{ Model } & \multicolumn{2}{|c|}{$\begin{array}{l}\text { Unstandardized } \\
\text { Coefficients }\end{array}$} & \multirow{2}{*}{$\begin{array}{c}\begin{array}{c}\text { Standardized } \\
\text { Coefficients }\end{array} \\
\text { Beta }\end{array}$} & \multirow[b]{2}{*}{$\mathrm{t}$} & \multirow[b]{2}{*}{ Sig. } \\
\hline & B & Std. Error & & & \\
\hline 1(Constant) & 26.580 & 8.112 & & 3.277 & .002 \\
\hline $\begin{array}{l}\text { Autonomy.Questionna } \\
\text { ire }\end{array}$ & .623 & .108 & .556 & 5.790 & .000 \\
\hline
\end{tabular}

a. Dependent Variable: WTC.Scale

The forth-coming tables are the indication of the degree of predictability that learner autonomy has for situational WTC. Table 4.11. Variables Entered/Removed ${ }^{\mathrm{b}}$

\begin{tabular}{llll}
\hline Model & Variables Entered & Variables Removed & Method \\
\hline 1 & $\begin{array}{l}\text { Autonomy.Questionna } \\
\text { ire }^{\text {a }}\end{array}$ & . Enter \\
\hline
\end{tabular}

a. All requested variables entered.

b. Dependent Variable: WTC.Tally.Chart

As Table 4.12 depicts the degree of correlation, i.e. $\mathrm{R}$ between the two variables, namely learner autonomy and situational WTC turned out to be 0.256 , and the R square is 0.065 . Based on the data in this table it can be said that learner autonomy can predict only 6.5 percent of situational WTC $(\mathrm{R}=.256$, $\mathrm{R}$ square $=.06)$.

Table 4.12. Model Summary

\begin{tabular}{|c|c|c|c|c|}
\hline Model & $\mathrm{R}$ & R Square & Adjusted R Square & $\begin{array}{l}\text { Std. Error of the } \\
\text { Estimate }\end{array}$ \\
\hline 1 & $.256^{\mathrm{a}}$ & .065 & .053 & 12.02518 \\
\hline
\end{tabular}

Table 4.13 indicates the results of the ANOVA which demonstrate that the ANOVA is significant $(\mathrm{F}=5.25, \mathrm{P}=.025<$ $.05, \omega^{2}=.05$; it represents a weak to moderate effect size).

\begin{tabular}{|c|c|c|c|c|c|c|}
\hline Model & & $\begin{array}{l}\text { Sum of } \\
\text { Squares }\end{array}$ & $\mathrm{df}$ & Mean Square & $\mathrm{F}$ & Sig. \\
\hline \multirow[t]{3}{*}{1} & Regression & 759.116 & 1 & 759.116 & 5.250 & $.025^{\mathrm{a}}$ \\
\hline & Residual & 10845.376 & 75 & 144.605 & & \\
\hline & Total & 11604.492 & 76 & & & \\
\hline
\end{tabular}

a. Predictors: (Constant), Autonomy.Questionnaire

b. Dependent Variable: WTC.Tally.Chart

In Table 4.14 coefficients are presented. According to this table Beta coefficient is significant $(\mathrm{B}=.256, \mathrm{t}=2.291, \mathrm{P}=$ $.025<.05)$. Based on the statistics presented in both Table 4.13 and Table 4.14, it could be expressed that learner autonomy significantly predicts situational WTC; although, the results should be interpreted cautiously due to weak to moderate value of the effect size index.

Table 4.14 Coefficients ${ }^{\mathrm{a}}$

\begin{tabular}{|c|c|c|c|c|c|c|}
\hline \multirow{2}{*}{\multicolumn{2}{|c|}{$\backslash$ Model }} & \multicolumn{2}{|c|}{$\begin{array}{l}\text { Unstandardized } \\
\text { Coefficients }\end{array}$} & \multirow{2}{*}{$\begin{array}{c}\begin{array}{c}\text { Standardize } \\
\mathrm{d}\end{array} \\
\text { Coefficients } \\
\text { Beta }\end{array}$} & \multirow[b]{2}{*}{$\mathrm{t}$} & \multirow[b]{2}{*}{ Sig. } \\
\hline & & B & Std. Error & & & \\
\hline 1 & (Constant) & -8.702 & 16.488 & & -.528 & .599 \\
\hline & $\begin{array}{l}\text { Autonomy.Question } \\
\text { naire }\end{array}$ & .501 & .219 & .256 & 2.291 & .025 \\
\hline
\end{tabular}


Again, the comparison of the regression analysis for both trait-like and situational WTC is in line with the abovementioned fact that a person may have a high WTC but when put in the situation, they may not be willing to communicate because of many situational variables, e.g. familiarity with the topic, that influence their WTC. So it can be said that learner autonomy has a significant relationship with WTC and can significantly predict it, but because of many intervening variables in the situation an autonomous learner may not be so willing to communicate as they claim, i.e. trait-like WTC $(\mathrm{R}=.556, \mathrm{P}=.000<.05)$ and as they do, i.e. situational WTC due to the smaller magnitude of correlation $(\mathrm{R}=.256, \mathrm{P}=.025<.05)$ and a weak effect size.

In the end, it is important to stress that like any other research this research suffered from some limitations and delimitations; therefore, any conclusion, however to be made cautiously, should be interpreted in the light of those limitations and delimitations that the researcher had in conducting the research. The researcher also hopes that the results of this study come in handy for learners, teachers, material developers, curriculum designers, and policy makers to go hand in hand in order to create an atmosphere that is suitable for language teaching and learning and leads the learners to achieve their goals in learning the target language and become successful and independent learners who can use the target language easily whenever, wherever, and to whoever they wish autonomously.

\section{Conclusion}

In this study the relationship between learner autonomy and WTC in Iranian EFL learners was investigated, and based on what was found through data analysis, it was shown that there is a significant and strong relationship between learner autonomy and trait-like WTC in Iranian EFL learners $(r=.55, \mathrm{P}=.000<.05)$ and a significant but weak relationship between learner autonomy and situational WTC in Iranian EFL learners $(r=.25, P=.025<.05)$. Therefore, it can be concluded that there is a statistically significant relationship between learner autonomy and WTC of Iranian EFL learners, and the null hypothesis, there is no statistically significant relationship between learner autonomy and WTC of Iranian EFL learners, was rejected.

The regression analysis done in this study regarding the predictability that learner autonomy may have for WTC, both trait-like and situational, would provide further support for the conclusion. Based on this analysis, it can be seen that learner autonomy significantly predicts trait-like WTC $\left(\mathrm{R}=.556, \mathrm{R}\right.$ Square $=.30, \mathrm{~F}=33.52, \mathrm{P}=.000<.05 \omega^{2}=.29, \mathrm{~B}$ $=.556, \mathrm{t}=5.79, \mathrm{P}=.000<.05)$. On the other hand, it can also be seen that learner autonomy significantly predict situational WTC $\left(\mathrm{R}=.256, \mathrm{R}\right.$ square $\left.=.06, \mathrm{~F}=5.25, \mathrm{P}=.025<.05, \omega^{2}=.05, \mathrm{~B}=.256, \mathrm{t}=2.291, \mathrm{P}=.025<.05\right)$; although, the results should be interpreted cautiously due to weak to moderate value of the effect size index. So it can be claimed that learner autonomy significantly predicts WTC.

Based on the findings of this study it can be said that autonomous learners generally tend to be willing to communicate; however, some factors in the environment may increase or decrease the flow of their talk.

5.1 Pedagogical Implications

The results of this study may be useful and beneficial for learners, teachers, material developers, curriculum designers, and policy makers.

As a shift is obvious in the history of methodology in learners from passive participants to active learners and share holders in the process of teaching and learning, if learners tend to be successful they should become autonomous and develop a high WTC. But more important than this is the fact that when learners know how to and become autonomous in WTC they have reached the goal of their education and act independently in language use. Knowing the weaknesses, obstacles, and the methods of solving them autonomously, they are capable of having an unhindered communication when they like to do so.

Teachers would know that helping learners develop learner autonomy in WTC is a great assist to them to use all the opportunities they face to use the target language, and increase their WTC which also indirectly influences their being more autonomous out of the formal setting of the education.

As far as materials and curricula play a crucial role in education, providing materials and curricula that emphasize and leads to the development of learner autonomy and WTC and being autonomous in WTC is very important in teaching and learning.

Policy makers may also think about the ways of giving learners more freedom and delegating to them the power to be able to act independently, i.e. autonomously to some extend in their education and creating an atmosphere which requires the use of the target language which in turn requires a high WTC.

\section{References}

Barfield, A., Ashwell, T., Carroll, M., Collins, K., Cowie, N., Critchley, M., Head, E., Nix, M., Obermeier, A., \& Robertson, M. C. (2001). Exploring and defining teacher autonomy: A collaborative discussion. Proceedings of the College and University Educators' 2001 Conference, Shizuoka, Japan. Tokyo, Japan: The Japan Association for Language Teaching. Retrieved from http://www.encounters.jp/mike/professional/publications/tchauto.html

Barraclough, R. A., Christophel, D. M., \& McCroskey, J. C. (1988). Willingness to communicate: A cross-cultural investigation. Communication Research Reports, 5(2), 187-192.

Bekker, M. H. J., \& Assen, M. A. L. M. (2008). Autonomy-connectedness and gender. Sex Roles, 59(3), 532-544. doi:10.1007/s11199-008-9447-x

Benson, P. (2001). Autonomy in language learning. Retrieved from http://findpdfbooks.org/ebook/http://www.asahinet.or.jp/ gj7h-andr/asia2006/antonomous_learning.pdf

Benson, P. (2006). Autonomy in language teaching and learning. Language Teaching, 4(2), 21-40. doi: $10.1017 / \mathrm{S} 0261444806003958$

Benson, P. (2008). Teachers' and learners' perspectives on autonomy. In T. Lamb \& H. Reinders (Eds.), Learner and 
teacher autonomy. Concepts, realities, and responses (pp. 15-32). Amsterdam, the Netherlands: John Benjamins Publishing Co.

Birjandi, P., \& Amiri, M. (2011). Willingness to communicate in the first language acquisition: A case study on Iranian 2-year old kids. European Journal of Social Sciences, 23(1), 41-52.

Brown, H. D. (2007). Principles of language learning and teaching. New York, United States of America: Pearson Education Inc.

Burgoon, J. K. (1976). The unwillingness to communicate scale: Development and validation [Abstract]. Communication Monographs, 43(1), 60-96. doi:10.1080/03637757609375916

Cao, Y., \& Philp, J. (2006). Interactional context and willingness to communicate: A comparison of behavior in whole class, group and dyadic interaction. System, 34(4), 480-493. doi:101016/j.system.2006.05.002

Carson, L. (2008). Relatedness and learner autonomy: A case study of an adult refugee learning English in Ireland. Reflections on English Teaching, 6(2), 21-38.

Chan, B., \& McCroskey, J. C. (1987). The WTC scale as a predictor of classroom participation. Communication Research Reports, 4(2), 47-50.

Clement, R., Baker, S. C., \& MacIntyre, P. D. (2003). Willingness to communicate in a second language: The effects of context, norms, and vitality. Journal of Language and Social Psychology, 22(2), 190-209. doi:10.1177/0261927X03252758

Cohen, L., Manion, L., \& Morrison, K. (2007). Research methods in education (6 ${ }^{\text {th }}$ ed.). London, the UK: Taylor \& Francis Group.

Compton, L. K. L (2007). The impact of content and context on international teaching assistants' willingness to communicate in the language classroom. TESL-EJ, 10(4). Retrieved from: http://www.tesl-ej.org/pdf/ej40/a2.pdf

Cotterall, S. (1995). Readiness for autonomy: Investigating learner beliefs. System, 23(2), 195-205.

Cotterall, S. (2000). Promoting learner autonomy through the curriculum: Principles for designing language courses. English Language Teaching Journal, 54(2), 109-117.

Crookall, D., \& Ho, J. (1995). Breaking with Chinese cultural traditions: Learner autonomy in English language teaching. System, 23(2), 235-243.

Dafei, D. (2007). An exploration of the relationship between learner autonomy and English proficiency. The Asian EFL Journal Teaching Articles, 24(1), 5-30.

Dickinson, L. (1995). Autonomy and motivation; A literature review. System, 23(2), 165-174.

Donovan, L. A., \& MacIntyre, P. D. (2004). Age and sex differences in willingness to communicate, communication apprehension, and self-perceived competence. Communication Research Reports, 21(4), 420-427.

Dornyei, Z. (2001). Teaching and researching motivation. London, England: Pearson Education.

Egel, I. P. (2009). Learner autonomy in the language classroom: From teacher dependency to learner independency. Procedia Social and Behavioral Sciences, 1(1), 2023-2026. doi:10.1016/j.sbspro.2009.01.355

Fishbein, M., \& Raven, B. H. (1962). The AB scales: An operational definition of belief and attitude [Abstract]. Human Relations, 15(1), 35-44. doi:10.1177/001872676201500104

Freiermuth, M., \& Jarrell, D. (2006). Willingness to communicate: Can on-line chat help?. International Journal of Applied Linguistics, 16(2), 189-213.

Gremmo, M. -J., \& Riley, P. (1995). Autonomy, self-direction and self access in language teaching and learning: The history of an idea. System, 23(2), 151-164.

Haghi, M. (2009). The relationship between perceived self-efficacy and Iranian EFL learners autonomy (Unpublished master's thesis). Islamic Azad University, Science and Research Branch, Tehran, Iran.

Hashimoto, Y. (2002). Motivation and willingness to communicate as predictors of reported L2 use: The Japanese ESL context. Second Language Studies, 20(2), 29-70.

Hsiao, T. Y., \& Oxford, R. L. (2002). Comparing theories of language learning strategies: A confirmatory Factor analysis. The Modern Language Journal, 86(3), 368-383.

Hurd, S. (2005). Autonomy and distance language learner. In B. Holmberg, M. Shelly, \& C. White (Eds.), Distance education and languages: Evolution and change; New perspectives on language and education (pp. 1-19). Clevedon, the UK: Multilingual Matters Publications.

Jacobs, G. M., \& Farrell, T. S. C. (2001). Paradigm shift: Understanding and implementing change in second language education. TESL-EJ 5(1), A-1. Retrieved July 23, 2002, from http://www.kyoto-su.ac.jp/information/tesl-ej/ej17/al.html Kang, S. -J. (2005). Dynamic emergence of situational willingness to communicate in a second language. System, 33(2), 277-292. doi:10.1016/j.system.2004.10.004

Kumaravadivelu, B. (2006). Understanding language teaching; From method to post method. London, England: Lawrence Erlbaum Associates.

Lee, W., \& Ng, S. (2010). Reducing student reticence through teacher interaction strategy. ELT Journal, 64(3), 302313. doi:10.1093/elt/ccpo8o

Little, D. (1995). Learning as dialogue: The dependence of learner autonomy on teacher autonomy. System, 23(2), 175181.

Little, D. (2007). Language learner autonomy: Some fundamental considerations revisited. Innovation in Language Learning and Teaching, 1(1), 14-29. doi:10.2167/illt040.0

Littlewood, W. (1996). "Autonomy": An anatomy and a framework. System, 24(4), 427-435.

Littlewood, W. (1999). Defining and developing autonomy in East Asian contexts. Applied Linguistics, 20(1), 71-94.

MacIntyre, P. D. (2007). Willingness to communicate in the second language: Understanding the decision to speak as a 
volitional process. The Modern Language Journal, 91(4), 564-576.

MacIntyre, P. D., Babin, P. A., \& Clement, R. (1999). Willingness to communicate: Antecedents and Consequences. Communication Quarterly, 47(2), 215-229.

MacIntyre, P. D., Baker, S. C., Clement, R., Conrod, S. (2001). Willingness to communicate, social support, and language-learning orientations of immersion students. Studies in Second Language Acquisition, 23(3), 369-388.

MacIntyre, P. D., Baker, S. C., Clement, R., \& Donovan, L. A. (2002). Sex and age effects on willingness to communicate, anxiety, perceived competence, and L2 motivation among junior high school French immersion students. Language Learning, 52(3), 537-564.

MacIntyre, P. D., Clement, R., Dornyei, Z., \& Noels, K. A. (1998). Conceptualizing willingness to communicate in a L2: A situational model of L2 confidence and affiliation. The Modern Language Journal, 82(4), 545-562.

Mackay, A., \& Gass, M. S. (2005). Second language research: Methodology and design. New Jersey, the United States of America: Lawrence Erlbaum Associates.

Matsuoka, R., \& Evans, D. R. (2005). Willingness to communicate in the second language. Journal of Nurs Studies NCNJ, 4(1), 3-12.

McCroskey, J. C. (1977). Oral communication apprehension: A summary of recent theory and research. Human Communication Research, 4(1), 78-96. doi:10.1111/j.1468-2958.1977.tb00599

McCroskey, J. C., \& Baer, J. E. (1985, November). Willingness to communicate: The construct and its measurement. Paper presented at the Annual Meeting of the Speech Communication Association, Denver, Co.

McCroskey, J. C., \& Richmond, V. P. (1982). Communication apprehension and shyness: Conceptual and operational distinctions. Central State Speech Journal, 33(3), 458-468. doi:10.1080/10510978209388452

McCroskey, J. C., \& Richmond, V. P. (1987). Willingness to communicate. In J. C. McCroskey \& J. A. Daly (Eds.), Personality and interpersonal communication (pp. 129-156). Newbury Park, CA: SAGE Publications.

Milani, M. (2008). The effect of proficiency level, task type, and gender on Iranian adult students' willingness to communicate (WTC) (Unpublished master's thesis). Tarbiat Modares University, Tehran, Iran.

Noels, K. A., Pelletier, L. G., \& Vallerand, R. J. (2000). Why are you learning a second language? Motivational orientations and self-determination theory. Language Learning, 50(1), 57-85.

O’Malley, J. M., \& Chamot, A. U. (1990). Learning strategies in second language acquisition. Cambridge, the United States of America: Cambridge University Press.

Peng, J. E. (2007). Willingness to communicate in an L2 and integrative motivation among college students in an intensive English language program in China. University of Sydney Papers in TESOL, 2(1), 33-59.

Reinders, H., \& Wattana, S. (2011). Learn English or die: The effect of digital games on interaction and willingness to communicate in a foreign language. Digital Culture and Education, 3(1), 3-29.

Riasati, M. J., \& Noordin, N. (2011). Antecedents of willingness to communicate: A review of literature. Studies in Literature and Language, 3(2), 74-80. doi:10.3968/jsll.1923156320110302.326

Richmond, V. P., McCroskey, J. C., \& McCroskey, L. L. (1989). An investigation of self-perceived communication competence and personality orientations. Communication Research Reports, 6(1), 28-36.

Richmond, V. P., \& Roach, K. D. (1992). Willingness to communicate and employee success in U.S. organizations. Journal of Applied Communication Research, 20(1), 95-116. doi:10.1080/00909889209365321

Sallinen-Kuparinen, A., McCroskey, J. C., \& Richmond, V. P. (1991). Willingness to communicate, communication apprehension, introversion, and self-reported communication competence: Finnish and Americans comparisons. Communication Research Reports, 8(1), 55-64. doi:10.1080/08824099109359876

Scharle, A. \& Szabo, A. (2000). Learner autonomy: A guide to developing learner responsibility. Cambridge, the United States of America: Cambridge University Press.

Schmenk, B. (2005). Globalizing learner autonomy. TESOL Quarterly, 39(1), 107-118.

Seedhouse, p. (2004). The Interactional Architecture of the Second Language Classroom: A conversational Analysis Perspective. Oxford, England: Blackwell.

Smith, R. (2008). The history of learner autonomy. Paper presented at the Ninth Nordic Conference on Developing Learner Autonomy in Language Learning and Teaching: Status and Ways Ahead after Twenty Years, Copenhagen, Denmark. Retrieved from http://www2.warwick.ac.uk/fac/soc/al/research/groups/ellta/circal/dahla/histories/the_history_of_learner_autonomy.pdf Spratt, M., Humphreys, G., \& Chan, V. (2002). Autonomy and motivation: Which comes first?. Language Teaching Research, 6(3), 245-266. doi:10.1191/1362168802Ir106oa

Thanasoulas, D. (2000). Autonomy and learning: An epistemological approach. Applied Semiotics, 4(10), 115-131.

Ushioda, E. (2006). Language motivation in reconfigured Europe: Access, identity, autonomy. Journal of Multilingual and Multicultural Development, 27(2), 147-161. doi:10.1080/01434630608668545

Ustunluoglu, E. (2009). Autonomy in language learning: Do students take responsibility for their learning?. Journal of Theory and Practice in Education, 5(2), 148-169.

Varol, B., \& Yilmaz, S. (2010). Similarities and differences between female and male learners: Inside and outside class autonomous language learning activities. Procedia Social and Behavioral Sciences, 3(2010), 237-344. doi:10.1016/j.sbspro.2010.07.038

Victori, M., \& Lockhart, W. (1995). Enhancing metacognition in self-directed language learning. System, 23(2), 223234.

Wardhaugh, R. (2006). An introduction to sociolinguistics $\left(5^{\text {th }}\right.$ ed.). Oxford, the UK: Blackwell Publishing Ltd. Wenden, A. L. (1995). Learner training in context: A knowledge-based approach. System, 23(2), 183-194. 
White, C. (1995). Autonomy and strategy use in distance foreign language learning: Research findings. System, 23(2),

Yang, N. -D. (1999). The relationship between EFL learner's beliefs and learning strategy use. System, 27(4), 515-535.

Yashima, T. (2002). Willingness to communicate in a second language: The Japanese EFL context. The Modern Language Journal, 86(1), 54-66.

Yashima, T., Zenuk-Nishide, L., \& Shimizu, K. (2004). The influence of attitudes and affect on willingness to communicate and second language communication. Language Learning, 54(1), 119-152.

Yu, H., Li, H., \& Gou, X. (2011). The personality-based variables and their correlations underlying willingness to communicate. Asian Social Science, 7(3), 253-257.

$\mathrm{Yu}$, M. (2009). Willingness to communicate of foreign language learners in a Chinese setting (Doctoral dissertation, Florida State University, College of Education). Retrieved from: http://etd.lib.fsu.edu/theses/available/etd-03242009133306/unrestricted/YuMDissertation.pdf

Zakahi, W. R., \& McCroskey, J. C. (1989). Willingness to communicate: A potential confounding variable in communication research. Communication Reports, 2(2), 96-104.

Zarrinabadi, N., \& Abdi, R. (2011). Willingness to communicate and language learning orientations in Iranian EFL context. International Educational Studies, 4(4), 206-214. doi:10.5539/ies.v4n4p206. 